\title{
CONCEPÇÕES DE PROFESSORES DE SÉRIES INICIAIS DE 1ำ AO 5ㅇ ANO SOB TDAH: ESTUDO APLICADO
}

\section{ARTIGO ORIGINAL}

OUTEIRO, Roseli Aparecida Conrado da Rosa ${ }^{1}$

OUTEIRO, Roseli Aparecida Conrado da Rosa. Concepções de professores de séries iniciais de $1^{\circ}$ ao $5^{\circ}$ ano sob TDAH: estudo aplicado. Revista Científica Multidisciplinar Núcleo do Conhecimento. Ano 05, Ed. 09, Vol. 09, pp. 138-176. Setembro de 2020. ISSN: 2448-0959, Link de acesso: https://www.nucleodoconhecimento.com.br/educacao/professores-de-series, DOI: 10.32749/nucleodoconhecimento.com.br/educacao/professores-de-series

\section{RESUMO}

Este artigo teve como objetivo identificar as concepções dos professores de séries iniciais de $1^{\circ}$ ao $5^{\circ}$ ano de uma escola $\mathrm{x}$ da rede municipal de Araquari, Estado de SC e uma escola $X$ da rede Estadual de ensino do Município de Joinville, Estado de SC com relação ao transtorno de déficit de atenção e hiperatividade. Sendo que da Escola da rede Municipal de Araquari participaram três professores do gênero feminino e um masculino, e na Escola estadual de Joinville seis professores do gênero feminino; foram aplicados junto a eles um questionário semiaberto que possibilitava-Ihes responder segundo suas opiniões e concepções acerca do tema. No resultado das análises dos dados coletados, percebeu-se falta de informações, conhecimentos e saberes básicos específicos com relação sobre o que é o transtorno de déficit de atenção e hiperatividade bem como dificuldade de distinção dos sintomas comparativamente as demais crianças sem o transtorno em sala de aula, além de ausência de cursos de capacitação na área, o que seria de grande

\footnotetext{
${ }^{1}$ Pedagogia com licenciatura Plena em Séries Inicias; Pedagogia com Licenciatura Plena em Educação Infantil, Orientação Escolar, Supervisão Escolar e Gestão escolar; Especialista em Educação Especial; Pós-Graduação em Gestão e Metodologia do Ensino; Mestranda em Ciências da Educação.
} 
ajuda para os professores ao aprenderem a diferenciar os sintomas e aprenderem a lidar com as diferentes situações no seu espaço de atuação profissional devido aos sintomas que o transtorno acarreta no aluno; percebeu-se também que conta-se com escassos suportes didáticos, pedagógicos e de profissionais especialistas entendidos na área para orientações e embasamentos teóricos e práticos com relação ao processo de ensino/aprendizagem, a inclusão e interação adequada dessa parcela da sociedade, sabendo-se que pelo professor conviver muito tempo com as crianças podem observar seus comportamentos, sua autoimagem, sua interação com os demais da turma e com a família, e o impacto destes na aprendizagem.

Palavras chaves: transtorno de déficit de atenção e hiperatividade, inclusão, conhecimento, professor.

\section{INTRODUÇÃO}

Segundo Kaplan (1997), o problema da hiperatividade não se concentra no nome, mas sim nos sintomas específicos do transtorno, como a dificuldade de manter a atenção e agitação motora, que não condizem com a idade e fase de desenvolvimento da criança, vindo a se tornar bem perceptível pela acentuação desses sintomas.

Há muito se sabe da existência de alunos com esse transtorno nas redes regulares de ensino público, uma vez que que segundo Almeida (1996), já vem se tentando diagnosticar e tratar os pacientes hiperativos ao longo do tempo, sendo que somente em 1902 houve a primeira conceitualização desse transtorno por George Still, entretanto, apenas com grande incidências de encefalite no período da segunda guerra mundial é que surgiram os primeiros interesses por especialista da área pelo tema.

Antigamente as crianças com deficiências eram isoladas do convívio social, eram enclausuradas em torres de igrejas e residências usadas para estes fins como as 
antigas rodas dos expostos, criadas para confinar crianças pobres, idosos, deficientes e outras pessoas deixadas a margem da sociedade, tirando - os da ruas e das vistas da sociedade, da mesma forma as crianças hiperativas no início do século XX segundo Kaplan (1997) sendo que muitas dessas sofriam de encefalite que causava lesões neurológicas.

Atualmente muitas das crianças não são diagnosticadas, seja por falta de informação por parte dos professores e pais como de aceitação do problema por parte dos familiares o que prejudica e retarda ou mesmo impossibilita um tratamento adequado e preciso da criança ou adolescente que sofre deste mal, fatores estes defendidos nas falas de Topczewski (2008), o que inviabiliza os tratamentos adequados necessários para o promoção de bem estar, socialização e inclusão social das crianças que sofrem com esse transtorno em especifico, sendo que estes é perdem e muito sob todos os aspectos do desenvolvimento integral infantil e deixa de aprender e se desenvolver como de direito e como poderia através das interações saudáveis e comuns correspondente a idade escolar.

Acredita-se que o quadro de sintomas desse transtorno é mais perceptível no meio familiar e escolar, ambientes onde a criança ou adolescente passa a maior parte de seu tempo e onde exige-se mais dela como atenção, concentração, foco, memorização, rendimento nas suas atividades, cuidados efetivos com seus pertences, mais tempo sentado e parado para ouvir, ver, ler e observar tudo que acontece em seu entorno. Por esses e outros fatores o professor e a família são os agentes mais viáveis para conhecer, identificar e prestar auxílio adequado a estes em suas necessidades especificas e diárias, mas nada disso é possível se a família e os professores desconhecerem a existência do transtorno e seus respectivos sintomas bem como a criança ou adolescente que está sob sua responsabilidade.

A falta de encaminhamento e cuidados específicos por parte de especialistas no assunto e tratamentos ainda na infância, assim que identificados todos os sintomas em pelo menos dois ambientes para que se possa diagnosticar uma criança como 
tendo TDAH, vai repercutir na vida da criança e ou adolescente a curto e a longo prazo, e por consequência influencia a vida de todos a seu redor devido aos sintomas indissociáveis do déficit de atenção e hiperatividade e a falta de controle inibitório de seus impulsos e comportamentos, conforme o autor (TOPCZEWSKI, 2008). O que é inevitável, uma vez que a criança tendo TDAH carregará os sintomas consigo e manifestar-se-ão nos mais diversos espaços, dependendo das circunstâncias, estímulos e do ambiente. A tendência é ser mais predominante e percebida em casa e na escola onde convive a maior parte do tempo.

A escolha desse tema para esta pesquisa se deve ao desafio pedagógico e comportamental que um aluno de séries iniciais, hiperativo e com déficit de atenção, oferece ao professor em sala de aula. A necessidade de buscar mais conhecimento, subsídios para a práxis pedagógica bem como suportes com técnicas de manejo e metodologias assertivas e direcionadas a essa especificidade em questão, visando favorecer e facilitar todo o processo de ensino aprendizagem de forma inclusiva e paralelamente melhorar suas interações com todos a seu redor.

Esta pesquisa teve como objetivo geral compreender como se dá as interações escolares entre o meio educativo de forma globalizada e a criança ou adolescente com déficit de atenção e hiperatividade, bem como entender a percepção do professor com relação aos problemas comportamentais da criança com transtorno de déficit de atenção e hiperatividade (TDAH). Como objetivos específicos respectivamente, visou-se buscar primeiramente aprender como o professor de séries iniciais de uma escola pública pode agir junto a crianças com déficit de atenção hiperativas / impulsivas, de modo a favorecer seu processo de ensino /aprendizagem; assim possibilitando na sequência, analisar as relações entre professor-aluno em sala de aula e a dinâmica interacional que se estabelece; verificar o que o professor sabe sobre o tema TDAH e como último mais não menos importante objetivo aprofundar conhecimentos e aprimorar a práxis didática e pedagógica. 


\section{O QUE É TDAH}

Sobre este tema tão polêmico e mal compreendido por muitos profissionais da educação, da família e da sociedade como um todo, o DSM IV é um documento internacional vem destrinchar melhor o que é esse transtorno, suas características para diagnosticar, características, o que vem de encontro da necessidade de se ter uma fundamentação teórica oficializada, que transmite segurança um uma vez que se passa a compreender melhor as possíveis causas, origens, termos e significados do que é efetivamente o transtorno de déficit de atenção e hiperatividade e como se classificam entre si.

O TDAH que antigamente era conhecido como "Disfunção Cerebral Mínima", mais tarde passou a chamar-se "Síndrome Infantil da Hiperatividade" e então nos anos 70 com o reconhecimento da ausência de controle de impulsos e do componente déficit de atenção, passou então a ter a denominação a qual perdura até os dias de hoje: Transtorno de Déficit de Atenção e Hiperatividade, (DSM IV)

A característica essencial do Transtorno de Déficit de Atenção/Hiperatividade é um padrão persistente de desatenção e/ou hiperatividade, mais frequente e severo do que aquele tipicamente observado em indivíduos em nível equivalente de desenvolvimento (Critério A). Alguns sintomas hiperativoimpulsivos que causam prejuízo devem ter estado presentes antes dos 7 anos, mas muitos indivíduos são diagnosticados depois, após a presença dos sintomas por alguns anos (Critério B- DSM IV).

Luis Augusto P. Rohde em seu livro (2008) "Transtorno de déficit de atenção hiperatividade", traz um estudo de caso de uma criança denominada Pedro de 8 anos com TDAH, e as dificuldades que ele encontra no convívio escolar e na família, devido aos sintomas de seu problema, principalmente as consequências e formas errôneas dos pais, professores e colegas lidarem com o mesmo, por não conhecerem e não entenderem suas atitudes comportamentais, sua falta de atenção, de concentração, de manter o foco numa coisa de cada vez, em se dispersar-se muito rapidamente, em não conseguir dar a devida atenção e ouvidos as falas e explicações da professora, a falta de zelo e cuidado com seus pertences e esquecimento dos mesmos em casa em dias de aula, a não realização de suas 
atividades passadas pela professora, o não saber respeitar a vez do colega e ser o centro de atenção dos adultos o tempo todo interrompendo as conversas dos mesmos com frequência, enfim, ele esclarece numa linguagem acessível para tantos os pais, familiares como professores entenderem melhor e aprenderem a lidar com a pessoa com TDAH e com suas peculiaridades e singularidades, ajudando a apreender a lidar e controlar principalmente seus impulsos comportamentais e aumentar sua capacidade de atenção e concentração, aprimorando seu processo de ensino aprendizagem e desenvolvimento por consequência, além de facilitar a vida de todos a seu redor, diminuindo os atritos e conflitos que suas posturas incontroláveis causava.

Topczewki na sua obra citada acima apresenta segundo seu entender o que é o TDAH da seguinte forma:

[...] desequilíbrio bioquímico provocado pela produção e reaproveitamento inadequados dos neurotransmissores (dopamina, adrenalina, serotonina) em certas regiões do cérebro (pré-frontal, parietal, sistema límbico, núcleos da base, cerebelo, sistema reticular ascendente) responsáveis pelo nível de atenção, controle das emoções, controle motor e estado de vigília. Essa desorganização bioquímica interfere no desempenho das diversas atividades, denominadas executivas, que necessitam percepção, planejamento, monitoração e organização para a correta elaboração execução das tarefas. Portanto, essas alterações bioquímicas modificam o comportamento neurofisiológico, pois interferem nos mecanismos do sono e vigília, favorecem o aparecimento do comportamento agressivo, impulsivo, depressivo e os distúrbios da atenção. (TOPCZWESKI, 2008, p. 42).

O transtorno de déficit de atenção e hiperatividadelimpulsividade é tema e objetivo de pesquisa mais intensivas desde a década de 90 de acordo com Luis Augusto Rohde e Paulo Mattos (2008), conforme suas pesquisas e relatos, as causas do transtorno ainda não são precisas: Há diversas hipóteses baseadas em experiências, observações, tratamentos medicamentosos e terapêuticos, podendo ser hereditário, devido a problemas durante a gravidez e parto, exposição a chumbo, fumo, álcool, uso de drogas e entorpecentes durante a gestação, problemas familiares, alimentação com aditivos ou conservantes entre outras causas (ROHDE e MATTOS, 2008), reiteradas por (TOPCZEWSKI, 2008; ROHDE e BENCZIK, 2010), 
que citam também psicopatia na família, comportamentos agressivos e desentendimentos familiares. Benczik (2010, p.62) relata que:

[...] em 1993, foi publicada uma pesquisa mostrando que pacientes com um raro tipo de deficiência de hormônio tireoidiano associada a fatores do TDAH"... O modelo mais aceito no momento para explicar as causas do TDAH é o de sua vulnerabilidade herdada ao transtorno que vai manifestar-se de acordo com a presença de desencadeadores ambientais. Quanto mais forte a carga genética, menor a importância dos desencadeadores ambientais. (ROHDE e BENCZIK, 2010, p. 62)

Rohde e Benzick discorrem sobre os detalhes com relação ao funcionamento neural a nível neurobiológico e a origem da hiperatividade de acordo com seus achados, experiências, observações e constatações e com relação sobre como isso afeta no comportamento e nas interações do sujeito.

Conforme Rohde Benczik (1999), o TDAH é um dos transtornos mais comuns na infância, se classificando como uma deficiência neurobiológica hereditária, caracterizada pela inabilidade de domínio motor, que se mostra acentuado, repentinos e inconvenientes, que provocam mudanças de humor e falta de estabilidade emocional e afetiva, não sendo única e sim variável de indivíduo para indivíduo. Muito prejudicial a suas interações na família, na escola, nos ambientes que convive. Os sintomas específicos desse transtorno é falta de atenção, a agitação e impulsividade o que tira a atenção da criança com constância, impossibilitando sua concentração, memorização, perda de objetos, dificuldades de seguir instruções e de organizar-se interna e externamente, falar demasiadamente, interromper falas, não respeitar a vez do outro e esperar a sua vez, e antecipar respostas demonstrando falta de paciência para esperar a pessoa acabar de se comunicar e questionar.

Conforme Goldstein (2006) para ser diagnosticar alguém com déficit de atenção e hiperatividade, há que se apresentar de forma bem acentuada os fatores de falta de atenção, descontrole motor significativo de forma impulsiva, de tal forma que venha causar danos na vida acadêmica do indivíduo e estar presente ao menos 
continuamente por um período aproximado de 6 meses e ser evidente e constante em mais de que um ambiente, tal qual no âmbito familiar e escolar.

Não há uma precisão sobre quando o TDAH tenha sido descoberto, apesar de tantas conjecturas, pesquisas, estudos, hipóteses, relatos de médicos e pesquisadores desde o período da II guerra mundial. Há fontes que relatam estudos e observações a nível cerebral e no funcionamento da rede neural e suas conexões e ritmos de sinapses, com pausa, ausências e presença de conexões. Silva constata que no Brasil o médico clínico tem feito uso de um exame denominado SPECT, similar ao PET-SCAN, mas por ser uma tecnologia e aparelhagem ainda muito restrita no País, as análises e diagnósticos na grande maioria ainda são realizados a nível de consultório psiquiátrico com base em dados empíricos, através de observações e anamnese fornecido pela família e escola, sessões terapêuticas psicológicas, acompanhamentos psicopedagógicos, pedagógicos e neurológicos, tendo como padrão os quadros e quantidades de sintomas apresentados nos diferentes ambientes. $O$ transtorno diverge em cada indivíduo, exigindo cuidado com a padronização para não incorrer em erros de diagnósticos e por consequência de intervenções medicamentosas. Kaplan diante de diversas teorias defende que:

Há a teoria de que o déficit de atenção possa ser causado pelo QI baixo, o que não comprova que toda criança ou adolescente com Déficit de Atenção e Hiperatividade tenha QI baixo e quanto a essa hipótese Pennington (1997), constata que o sujeito hiperativo em relação as crianças sem o transtorno aponta um QI menor e devido a esse fator teria mais dificuldades para tomadas de decisões pertinentes as funções executivas, exibindo maiores apertos diante de atividades que exigem maior concentração, atenção, raciocínio lógico e tomadas de decisões rápidas, como optar por uma direção a se seguir em um ambiente desconhecido e que requerem objetividade, agilidade, iniciativa e segurança, o autor cita que tais crianças usadas nesses experimentos demonstraram dificuldades motoras e demora em suas respostas voluntárias e involuntárias. 
Ainda sobre as causas possíveis do TDAH, Sobrinho (1999) vem elencar diversas possibilidades de causas para a origem do déficit de atenção e hiperatividade, como por exemplo, possível consequência de um ambiente problemático como família desestruturada ou conflitos escolares, desestabilizados emocionalmente e psicologicamente com problemas de depressão, ansiedade, outras possíveis patologias, falta e afetividade, deficiência sensorial ou mesmo sequelas e contraindicações medicamentosas, o que o autor reforça dentro dessas páginas que, drogas tais quais a "teofilina, o fenobarbital e outras drogas para convulsão" poderiam aflorar o déficit de atenção; bem como poderia ser causado por desequilíbrio do hormônio da hipófise responsável por problemas na tireoide o que não comprovações até então. Sobrinho ainda levanta a possibilidade de contaminações por toxinas ambientais, chumbos, pesticidas químicos, conservantes artificiais utilizados para preservação e maior longevidade dos alimentos industrializados e excesso de açúcar no organismo.

Ratey (1999) em seu livro "tendência a distração", também denomina ao fator hormonal como causa possível do TDAH, recomendando como forma de descartar um exame de hipertireoidismo que segundo eles é uma entre outras condições que devem assemelhar-se muito ao DDA.

Quanto a terminologia, legalmente se usam termos generalizados para parafrasear o significado de deficiências onde incluem as condutas típicas como também um tipo de deficiência que dificulta as interações sociais, colocando nos seguintes termos:

Art. $2^{\circ}$ Considera-se deficiência toda restrição física, intelectual ou sensorial, de natureza permanente ou transitória, que limita a capacidade de exercer uma ou mais atividades essenciais da vida diária e/ou atividades remuneradas, causada ou agravada pelo ambiente econômico e social, dificultando sua inclusão social, enquadrada em uma das seguintes categorias: I - deficiência física, II - deficiência auditiva, III - deficiência visual, IV - deficiência intelectual, V - surdo cegueira, VI - autismo, VII condutas típicas, VIII - deficiência múltipla." (Senado Federal, Senador Renan Calheiros, dezembro de 2006)

Vale ressaltar a definição de condutas típicas: 
Comprometimento psicossocial, com características específicas ou combinadas, de síndromes e quadros psicológicos, neurológicos e/ou psiquiátricos, que causam atrasos no desenvolvimento e prejuízos no relacionamento social, em grau que requeira atenção e cuidados específicos em qualquer fase da vida. (Segundo o Art. VII do PL 7699/06)

O TDAH pela legislação brasileira se enquadra como condutas típicas devido o fator hipercinético e ser um transtorno motor e afetar seu psicológico e mental, o que compromete e dificulta e afeta as interações sociais e seu processo de ensino aprendizagem e desenvolvimento educacional e pessoal nos mais diversos aspectos de da vida do indivíduo e das pessoas que convivem com ele, teoria também defendida na Política de Educação Especial do Estado de Santa Catarina (2006) o déficit de atenção e hiperatividade por si só, pelo diferencial de seus sintomas, por ser mais restrito a dificuldades de inibição e controle motor e de atenção, não se considera o TDAH como deficiência e sim "condutas típicas" derivadas desse transtorno, os quais causam danos as interações e ao rendimento escolar se fazendo necessário exercitar o direito ao atendimento educacional especializado, para mediar e favorecer o processo de ensino e aprendizagem como um todo.

As nomenclaturas têm mudado ao longo das décadas de acordo com as diversas experiências, observações e pesquisas realizadas, Silva (2009) de seu livro "mentes inquietas" traz breves relatos históricos desde 1902 e duas décadas após onde médicos americanos baseados nas pesquisas de George Frédéric Still e tendo em comum na época um surto de encefalite infantil, nomearam esse transtorno como "distúrbio de comportamento pós-encefalite" para explicar comportamentos infantis de algumas crianças que eram vistas por eles com "dificuldades de seguir regras, eram desatentas, hiperativas, propensas a acidentes e ameaçadoras a outras crianças devido suas atitudes hostis, o que Still classificava como um defeito maior e crônico de "controle moral", conforme suas falas pejorativas, as citava como desonestas, e frisou que a condição tem relação com a educação familiar ou depravação moral. Mais tarde denominaram o transtorno como "cérebro danificado ou lesionado" e para diferenciar as crianças que se destacavam mais cognitivamente e posteriormente denominaram então "lesão cerebral mínima" e para justificar 
observações baseadas em crianças sem nenhum dano ou histórico de trauma ou lesões físicas mudou-se novamente o termo para "disfunção cerebral mínima".

Stella Chess em 1960 usava o mesmo termo de Laufer, no entanto acreditava que essa hiperatividade era derivada a nível orgânico de acordo com a biologia do indivíduo e não sendo influenciado pelo funcionamento mental tão pouco ambiental e sim relativo genética individual de cada um, foi Chess juntamente com outros autores dessa década que deram início as escritas sobre "síndrome da criança hiperativa" abrindo caminho para uma visão diferenciada daquelas acreditadas até então.

Já Laufer em 1957, denominou de "hiperatividade infantil" o qual acreditava ser algo predominante do gênero masculino e que de acordo com a idade iria desaparecendo o que alguns estudiosos e especialistas atuais discordam.

O sintomas do TDAH pode limitar as atividades diárias e trazer comprometimentos comportamentais e psicossociais, urgindo um atendimento especializado, entendido como um direito pela legislação, como forma de mediar e facilitar o processo de ensino aprendizagem, bem como favorecer a inclusão escolar como uma ponte, para ajudar o sujeito a se direcionar, ser estimulado, se organizar e ser orientado no dia a dia, uma ferramenta hábil desenvolver as habilidades, competências e talentos do indivíduo e para isso torna-se emergentes desenvolvimentos de estratégias e recursos de intervenções para aprimorar o sujeito a nível inter e intrapessoal, como forma de facilitar $\mathrm{o}$ ato de aprender a lidar com o transtorno em si em sua integralidade.

\section{PREDOMINÂNCIA DOS TIPOS E SUBTIPOS DE TDAH DE ACORDO COM OS GÊNEROS}

Considerando o quadro de sintomas e pesquisas levantadas por (TOPCZEWSKI, 2008; ROHDE e BENCZIK, 2010), se chegou à conclusão de que o deficiente de atenção predomina no gênero feminino e a hiperatividade no gênero masculino

Disponível em: https://www.nucleodoconhecimento.com.br/educacao/professoresde-series 
numa diferença contrastante de 2 por 1 a 3 por 1 , sendo portanto em maior incidência a hiperatividade, no que concordam Dupaul e Stoner (2007) calcados numa pesquisa com criançaslalunos norte-americanos na qual prevaleceu a hiperatividade masculina sobre as meninas com déficit de atenção, da mesma forma se observou o fato nas escolas e instituições de ensino norte americanas.

Segundo Braga (1998, p.25) "a hiperatividade é classificada em subgrupos, de acordo com a etiopatogenia do comportamento hiperativo, hiperatividade 'verdadeira', hiperatividade situacional, hiperatividade reacional"

Rohde e Benzik (2010) constatam que há dois subtipos de TDAH, estabelecidos na seguinte ordem: o primeiro predominando a desatenção e 0 segundo a hiperatividade (agitação) e impulsividade, diferenciados pelos seus sintomas. O autor enumera os sintomas de ambos os subtipos de TDAH, sendo que os sintomas abaixo recaem sobre o DA (tipo predominantemente desatento):

1. Não prestar atenção a detalhes ou cometer erros por descuido;

2. Ter dificuldade para concentrar-se em tarefas ou jogos;

3. Não prestar atenção ao que lhe é dito ("estar no mundo da lua");

4. Ter dificuldades de seguir regras e instruções e $\backslash$ ou não terminar o que começa;

5. Ser desorganizado com as tarefas e materiais;

6. Evitar atividades que exijam um esforço mental continuado;

7. Perder coisas importantes;

8. Distrair-se facilmente com coisas que não tem nada a ver com o que está fazendo;

9. Esquecer compromissos e tarefas. (ROHDE e BENCZIK, 2010, p. 39-40).

Os fatores acima são motivos de muitas queixas escolares e familiares com relação aos meninos e são origens de conflitos, agressividade, exclusões nos momentos de 
brincadeiras infantis. Segundo Silva, a criança pode estar distraída e desligada do que acontece em sala de aula, entretanto, pode estar observando algo novo e com riqueza de detalhes que passam despercebidos dos demais, pensando na dinâmica, forma geométrica, linha de voo de uma abelha ou de um pássaro que esteja passando em frente à sua janela, nas cores destes, em sua plumagem, família a que pertença, pode estar fazendo conexões com a forma de planar semelhante a um beija flor que esteja na forma das hélices de um helicóptero, ou simplesmente criando uma história, fantasiando, lembrando de algo simplório ou muito marcante em sua vida, geralmente mostram-se muito criativos, daí a importância de buscar entender o que essa criança tem e seus potenciais e interesses pra melhor aproveitar seus talentos em algo que ela goste e portanto lhe seja significativo e útil, sendo motivada e aproveitada de acordo com suas aptidões e áreas de interesse.

Rhode e Benczik conceituam o significado de hiperatividade e impulsividade como segundo tipo e o mais grave em sua sintomatologia o qual requer mais atenção e cuidado. Os sintomas da hiperatividade ficam assim classificados:

1). Ficar remexendo as mãos elou pés quando sentado;

2). Não ficar sentado por muito tempo;

3) Pular, correr excessivamente em situações inadequadas, ou por ter uma sensação interna de inquietude (ter "bicho- carpinteiro por dentro");

4). Ser muito barulhento para jogar ou divertir-se;

5) Ser muito agitado (" a mil por hora", um foguete");

6). Falar demais;

7). Responder ás perguntas antes de terem sido terminadas;

8). Ter dificuldade de esperar a vez;

9). Intrometer-se em conversas ou jogos dos outros. (ROHDE e BENCZIK, 2010. p.40) 
De acordo com o autor as características da criança hiperativa na escola mais visíveis que podem facilitar a identificação deste transtorno são:

a) Movimenta-se excessivamente na sala de aulas;

b). Atrapalham a dinâmica das aulas;

c). Falam muito com os outros colegas;

d). Não prestam atenção e não conseguem se concentrar nas atividades;

e). Interrompe a professora com frequência;

f) Interfere de modo impróprio e inoportuno nas conversas dos outros alunos;

g). Tumultuam a classe com brincadeiras fora de hora;

h). Apresentam iniciativas descontroladas;

i). O desempenho global nas diversas atividades encontram-se em nível aquém da média do seu grupo. (ROHDE e BENCZIK, 2010. Pg. 33)

E há ainda o subtipo misto ou combinado, onde coexistem tanto o déficit de atenção como os sintomas de hiperatividade/impulsividade, somando-se os seis sintomas característicos de cada transtorno somam- se doze, o que agravam consideravelmente as interações da criança em todos os espaços bem como sua vida acadêmica, como constatam Rohde e Benczik (2010)

Há que se tem o cuidado ao observar atentamente os comportamentos das crianças em interação social e comparando com a intensidade e constância naturais de outras crianças de sua idade e de mesmo gênero e fase de desenvolvimento segundo as falas Mattos (APA, 2002; MATTOS, 2001), atentando-se para os sintomas predominantes a fim de se entender se a criança tem DA ou Hiperatividade, sintomas estes que tendem a serem mais evidentes em dois contextos, geralmente em casa e na escola onde estes permanecem a maior parte de seu tempo. 
Harpin (2005) lembra que pelas crianças serem naturalmente ativas, no período pré escolar é muito difícil distinguir a criança sem os sintomas do TDAH das demais, uma vez que as atividades e rotina destes abrangem muito movimento e agitação, no entanto conforme avança nas modalidades de ensino formal do ensino fundamental, onde se requer da criança uma maior habilidade de permanecer sentado e se concentrar nas atividades dirigidas, ficam mais perceptíveis e contrastantes os sintomas desses transtornos.

O Doutor Abram Topczewski (2008) cita que os sintomas das crianças com déficit de atenção e hiperatividade e questiona se as manifestações comportamentais são sempre percebidas, e constata que é relativa e circunstancial, por exemplo durante uma aula de educação física ou prática de esportes, colônias de férias, atividades que exigem muita movimentação igualmente de hiperativos ou não, não se percebe facilmente se fulano ou ciclano é hiperativo ou não, pois o movimento faz parte do momento, no entanto quando em férias a criança sozinha fica entediada, agitada, ansiosa, angustiada, se mexe o tempo todo o corpo, pés, mãos, não sabe o que fazer com as mãos, mexe em tudo, fala sem parar, corre demais, deixa os pais malucos, dá para perceber o que está dentro da normalidade de uma criança saudável e sem transtorno ou não, dependendo do nível de conhecimento dos pais, tempo de convivência e observação constante e continuada com o filho; do mesmo jeito na sala de aula, onde a ensino em seu processo integral já exige mais atenção, tranquilidade, concentração, ouvir, realizar atividades mais demoradas e até repetitivas como em matemática, que é mais abstrata e requer mais a funcionalidade mental para calcular, parar para tal, não se distrair com qualquer coisa, ficar sentado em sua carteira focado na explicação da professora, e o aluno com TDAH se porta totalmente ao inverso do que se faz necessário naquele momento em especifico, é de preocupar e parar para observar se é intencional ou não, se é só fase da idade ou vai além disso, para então chamar os pais, orientadores para conversar e verificar se há necessidade de procurar um profissional da saúde, um psicólogo e por conseguinte se necessário este encaminhar para um neurologista e ou psiquiatra para as intervenções adequadas a cada caso e com todos os envolvidos.

RC: 60944

Disponível em: https://www.nucleodoconhecimento.com.br/educacao/professoresde-series 
Sam Goldstein (psicólogo infantil) e Michael Goldstein (neurologista) escreveram uma série educação especial hiperatividade "como desenvolver a capacidade de atenção da criança"; constatam que a hiperatividade não tem cura mas controle, cabendo aos pais buscar por conhecer seus filhos e saber diferenciar no comportamento do filho o que faz parte da idade, buscar informações sobre o tema e dar suporte ao professor ajudando a entender os problemas comportamentais, o resultado potencial para um indivíduo em particular é determinado por diversos fatores". Não devem ser usados como base para entender a criança hiperativa, uma vez que as características variam de pessoa para pessoa, de acordo com suas personalidades, caráter e conceitos morais formados, ambientes, formas de se lidar com os mesmos, nível de conhecimentos de escola, pais, da sociedade onde convive.

O Diagnóstico da criança hiperativa ou com déficit de atenção, cabe aos especialistas da área em questão, como os neurologistas, psiquiatras e psicólogos que formam uma equipe multidisciplinar, que somente laudam após cuidadoso estudo e pesquisa do caso baseado em todos os seus sintomas e na quantidade de lugares que apresenta as mesmas características. Se rotula com frequência de hiperativa ou com supostos transtornos erroneamente a tais características comuns, a "[...] comportamentos próprios da idade em crianças ativas, tais como, correrias e barulho excessivo" (APA, 2002, p. 117).

Conforme Rappley (2005) numa taxa de $80 \%$ dos casos diagnosticados de TDAH, os sintomas do tipo combinado se fundem, apresentando o indivíduo tanto o déficit de atenção como a hiperatividade, e nos $20 \%$ restante se mostram um aspecto do transtorno mais contrastante que os outros, requerendo um cuidado muito grande na observação de todos os sintomas apresentados num período mínimo de 6 meses para não se incorrer no risco de um diagnóstico, laudo e tratamento errôneo. 


\section{COMORBIDADES DO TDAH X TRANSTORNO OPOSITOR}

Há risco de surgir comportamento opositor a autoridades e regras de convivência impostas por adultos e autoridades, conforme DuPaul e Stoner (2007) e Rohde e Mattos (2008) citam, referindo-se ao transtorno opositor desafiante (TOD) e ao transtorno de conduta (TC), além de abuso de substâncias psicoativas; depressão; ansiedade; angústia; prevalência de transtorno bipolar com mudança de humor; a frequente associação com o transtorno de Gilles de La Tourette (ROHDE e MATTOS, 2008; DUPAUL e STONER, 2007).

Barkley (1998), relata que o nível de stress é muito intenso por parte de pais de filhos com TDAH durante as intervenções e acompanhamentos de crianças de 3 a 6 anos, e quando associada de comorbidade e transtorno de oposição é ainda pior, com o tempo se reduzem, mas comparado a grupos de controle são muito mais expressivos.

Sendo que a ansiedade, agitação interna e externa especificas do TDAH, são causas de grandes conflitos entre escola e família por se tornar muitas vezes um problema no processo de ensinar e aprender, por além de prejudicar sua própria aprendizagem também interferir na didática de sala de aula quando nem a criança nem o professor e tão pouco os pais sabem como lidar com a agitação exacerbada oriunda da hiperatividade, que a criança ou adolescente por si geralmente não consegue dominar, Harpin (2005) fala que:

[..] Para Harpin, características negativas podem estar associadas aos diferentes estágios de desenvolvimento. São acumuladas, podendo levar a sérios comprometimentos futuros: baixa autoestima até os sete anos, problemas de comportamento, atraso na aquisição do repertório acadêmico e déficit em habilidades sociais até os 11 anos. Dos 13 anos até a idade adulta, comportamento desafiador e opositivo, comportamento criminoso, expulsão da escola, abuso de substâncias, baixa motivação e dificuldades de aprendizagem. (HARPIN, 2005).

Uma vez que a criança ou adolescente não tem em quem se esmerar e se refugiar ante a necessidade de intervenções, encaminhamento a tratamentos específicos, 
fica totalmente a própria sorte e da mesma forma a escola sem ninguém para dar suporte e apoio ao professor em sala de aula. Faltando assim conforme acreditam os autores, o fator de proteção mais importante, uma boa estrutura familiar baseada em diálogo, respeito, motivação e bom status econômico financeiro familiar, que possibilita a busca e encaminhamento a tratamento mental ou psiquiátrico e psicológico para ajudar a mediar e intervir nas possíveis situações de risco, tão benéficos a curto e longo prazo. Em segundo lugar a educação, uma educação de qualidade e aberta, direcionada para lidar com os conflitos, com as diferenças e diversidades ressalvados de um suporte técnico, psiquiátricos, psicológicos e psicopedagógicos.

\section{BENEFÍCIOS POSSÍVEIS DERIVADOS DO TDAH}

Silva (2009) em seu livro "Mentes inquietas," traz sua compreensão quanto a origem do déficit de atenção e hiperatividade, e usa o termo TDA tanto para denominar o transtorno de déficit de atenção como o transtorno de hiperatividade de forma isolada, com ou sem o déficit de atenção, o qual diz que a mente do TDA não é um órgão danificado, com problemas, com defeito e sim apenas difere dos demais na sua funcionalidade, na forma que atua e afeta as habilidades de atenção, de impulsos e motor, bem como acredita que o transtorno em si assim como provoca conflitos nos diversos espaços e ambientes como familiares, trabalhos, escolas devido à dificuldade de manejo dos sintomas do transtorno, da mesma forma pode ser muito benéfico no sentido de aguçar os sentidos muito úteis aqueles que tem aptidões artísticas, capacidade de iniciativa, autonomia, espirito de liderança e rapidez de raciocínio, ação e reação ante os problemas, os quais podem e costumam afetar não apenas o indivíduo que tem o transtorno como a todos ao seu redor. Sendo que os sintomas e o grau de gravidade diferem de indivíduo cada um de forma singular em cada organismo, de acordo com o funcionamento do trio de base. 
Silva (2009) conta que sempre que pensa em alguém TDA, lhe vem a memória a história do patinho feio, o qual inclusive dentro de sua família e inclusive por parte de sua mãe sofre rejeição, discriminação, preconceito e rotulação por mostrar traços de alguém desengonçado, desajeitado, desastrado, feio, diferentes dos seus em todas as suas características e comportamentos, forma de ser e agir. Ela relaciona esse personagem a pessoas com déficit de atenção e hiperatividade que assim como aquele patinho feio se descobriu ser um lindo cisne, cheio de criatividade, habilidades, capacidades, talentos, os quais apesar das intempéries da vida encontraram seus caminhos, fizeram suas oportunidades de forma intuitiva. Sozinhos conseguiram encontrar formas de explorar e ampliar suas habilidades naturais como cita a autora.

Ana Beatriz sugere uma possibilidade quanto ao funcionamento e função do lado direito do hemisfério cerebral:

[...] caso haja um excesso de ativação do hemisfério direito, (como acredita Robert Ornstein autor do livro A Mente Aberta) ocorrerá toda uma exacerbação dos processos citados acima. Isso pode ser exatamente o que ocorre com os cérebros TDAs. Seguindo essa linha hipotética, observamos que, por terem uma visão contextual (global) exacerbada, os TDAs teriam toda uma gama de pensamentos alternativos que os levariam a ver a vida sob um novo foco, criando, assim, o terreno ideal para o exercício da criatividade. É como imaginar o mundo sob uma visão míope. Tiram-se os óculos, e tudo muda de foco. Talvez tenha sido assim que pintores impressionistas, como Monet, revolucionaram o mundo da pintura colocando-a sob uma nova ótica de traços, cores e sentimentos. (SILVA, 2009, p. 117)

A dislexia é uma das comorbidades passiveis do TDAH, sobre isso Silva traz algumas falas e nomes famosos na história que tinham comportamentos semelhantes ou algum transtorno ou síndrome, mesmo sendo excluídos socialmente e da vida acadêmica se sobressaíram por si mesmos e mostraram uma história de auto superação.

Conforme Rubino (2008) disléxicos como forma de compensar suas dificuldades, estimulam e desenvolvem mais habilidades criativas, por isso se destacam mais nesse aspecto e no meio artístico a exemplo de grandes nomes renomados como 
Albert Einstein, Thomas Edison, Walt Disney e Agatha Christie, que deixaram suas marcas na história e no tempo sobressaindo a todas as suas dificuldades derivadas da dislexia, mostrando-que não são muito mais que isso e não são fruto de seu transtorno, elas tem o problema mas não são o problema, mas fazem e acham neles a solução de suas vidas resignificadas pelo que são e não pelo tem e apresentam.

Albert Einstein com ideias a frente de seu tempo deu muito o que falar, descobriu a lei da relatividade intuitivamente, e, no entanto, teve uma história de exclusão escolar e muitos conflitos e rebeldia, irreverência sempre relacionado a imagem dele mostrando a língua. Sempre inquieto, agitado, sem paciência para burocracias e protocolos de procedimentos científicos, muito opositor e polêmico com relação a outros colegas cientistas que procuravam métodos mais seguros e diferenciados de sua forma de pensar e agir.

De acordo com Silva (2009), Einstein não se adaptou ao sistema de ensino formal e tradicional de sua época, mostrou-se rebelde, com dificuldades de memorização, atenção, organização, desinteressado na maioria dos momentos e atividades das diversas disciplinas curriculares, demonstrando hiperconcentração apenas em temas que Ihe despertavam o interesse, nos quais se destacava encontrando caminhos e estratégias alternativas e diferenciadas de processar o aprendizado e execução das mesmas de forma intuitiva, e foi assim que refletindo sobre as problemáticas de tempo e espaço formulou a teoria da relatividade sobre a qual ele explica como a descobriu:

Como foi que aconteceu que tenha sido eu a pessoa a desenvolver a Teoria da Relatividade? A razão, penso eu, é que um adulto normal nunca para pensar sobre problemas de espaço e tempo. Essas são coisas nas quais ele pensou quando criança. Mas o meu desenvolvimento intelectual foi retardado, como resultado de eu ter começado a me perguntar sobre espaço e tempo somente quando já tinha crescido. Naturalmente eu pude ir mais fundo no problema do que uma criança com capacidades normais... (SILVA, 2009, p. 137)

Fernando Pessoa também demonstrava traços de TDA, passando a seus leitores a impressão de inquietação, contradição, desorganização, devaneios, 
hiperconcentração, criatividade, intolerância ao tédio, dificuldades em seguir regras. No poema "Liberdade" transpassa tudo isso e vai além. (SILVA, 2009)

Henry Ford, considerado o pai da indústria automobilística e da linha de produção em série, frentes fragmentadas por setor de peças por peças, como estratégia para agilizar a produção em tarefas repetitivas e especializadas. "Sua inquietação contra o velho sistema fez com que viesse a romper com as regras do mercado ao aumentar os salários dos seus empregados e diminuir a carga de trabalho", demonstrando uma personalidade forte, persistente, revolucionário, ousado e corajoso para romper regras pré estabelecidas pela sociedade capitalistas e ao mudar sua própria regra futuramente, com término da primeira guerra mundial quando passou a pintar os carros na cor que as pessoas gostavam e não só de preto como preferia e fazia até então.

Outros nomes como James Dean e Ayrton Senna são lembrados, por viverem sempre no limite da velocidade, inquietos, impulsivos, comportamentos tipicamente TDA.

Leonardo Da Vinci segundo Silva (2009) apesar de ser considerados por muitos de seu tempo como um fracassado devido não ter concluído muitas de suas obras, se destacou nas mais diversas áreas devido sua grande capacidade criativa e talento, mas apesar de toda sua engenhosidade e inteligência Da Vinci mostrava -se depressivo e triste, com sede de liberdade, chegando a ir ao mercado e comprar muitos passarinhos para soltar em seguida, e também pela sua própria fala "Muitos veem, mas não enxergam". Leonardo tinha muitas características de um TDA, entre outras coisas como, criação de projetos simultâneos, habilidades e talentos que o destacaram como pintor, arquiteto, botânico, urbanista, cenógrafo, cozinheiro e inventor, no entanto por ser inconstante começava a fazer projetos simultâneos e demorava para conclui-los a exemplo da pintura da capela cistina, que conforme relatos saia de casa ia e dava uma pincelada e voltava para sua casa, demorando uma eternidade para findar essa pintura cujo resultado esplêndido fez história e 
continua fazendo, da mesa forma que outros projetos seus inacabados como do helicóptero entre outros.

Marlon Brando com pai alcoólatra, padrões educativos muito rígidos e autoritários, motivo pelo qual foi servir a academia militar, mais inquieto, não suportando a rotina, a calmaria e tédio do lugar, foi expulso por indisciplina. Se tornou ator mais tarde e improvisava suas falas seguindo sua intuição, criatividade, ousadia, motivo de muitos conflitos com diversos diretores do cinema e razão de tamanho sucesso. Entretanto, tinha baixo estima, depressão e problemas com bebidas e compulsão sexual, não criava vínculos em suas relações. Através da arte cênica de seu jeito, se movimentou a favor dos índios, das minorias, os injustiçados e várias outras causas e compreendia que estava tentando melhorar um mundo de guerras, ódios e amores, através de seus filmes de faroeste no Oeste Selvagem onde os índios da região eram perseguidos, expulsos de suas terras e mortos em confrontos violentos numa guerra de poder pelas terras que os ingleses tanto cobiçavam. Seu problema emocional instável devida a família desestruturada, que só focava em seu lado negativo conforme sua fala, após sua mãe lhe fazer uma visita anos depois de sair do exército e estar famoso no cinema, chorando e caindo em uma crise de ansiedade e depressão, desabafou " "Seriam necessários muitos anos para que eu deixasse de aceitar o que me foi ensinado, durante a minha infância: que eu era um inútil", o que o fez procurar ajuda de especialistas e fazer análise posteriormente.

Wolfgang Amadeus Mozart, compositor desde os 4 anos e já explorado pelo pai, uma mente que não parava, com sérios problemas para dormir, parar de pensar e criar, bem típico do cérebro TDA, sempre desempenhando mais de um projeto de cada vez, com criatividade artística incomparável e com baixa estima, problemas financeiros e com bebidas.

Aos 17 já compunha 22 composições sacras e 21 sinfonias, 6 quartetos, 18 sonatas para violino e cravo, além de serenatas, divertimentos, danças e uma infinidade de peças menores...O seu comportamento durante sua curta e brilhante existência apresentou sinais de um TDA com perfil desbravador e artístico. Mozart era irrequieto, impulsivo e mostrava-se resistente as normas

RC: 60944

Disponível em: https://www.nucleodoconhecimento.com.br/educacao/professoresde-series 
estabelecidas. Considerava enfadonhas as operas antigas e por isso inovou com as inesquecíveis Dom Giovani e A Flauta Mágica.... (SILVA, 2009, p. 145)

Ao ser questionado sobre como se dava seu processo criativo responde que:

Como é que eu trabalho e como executo grandes composições musicais? Não posso na realidade the dizer senão isso: quando me sinto bem-disposto, seja em carruagem quando viajo, seja de noite quando durmo, acodem-me ideias aos jorros, soberbamente. Como e donde eu não sei. (SILVA, 2009, p. 145)

Ainda Segundo Silva (2009), Ludwing Van Beethoven intitulado 'O maestro que transforma o silêncio em música", teve uma vida de exploração por parte do pais como Mozart; sexto filho de cinco irmãos deficientes, tinha um talento e habilidade natural, aprendeu música desde cedo obrigado por seu pai, mas tinha dificuldade em se apresentar para os nobres da época que o ridiculizaram e taxaram de farsa, e seu professor de composição, Albrechtsberger, o rotulava de indisciplinado e dizia que nunca aprenderia nada de música e que era um caso perdido como compositor. Com o tempo mostrava-se irrequieto. Polêmico e num mundo em que era incompreendido, quando estava em processo de criação distraído e disperso, seus amigos falavam que ele era acometido de devaneios e distrações, sintoma de DA. Compôs "Pour Elise" que o destacou no mundo da música, entretanto perdeu a audição, entrou em depressão, se isolou de todo mundo, se tornou melancólico e todos o consideram como acabado inclusive ele mesmo, a ponto de pensar em suicídio, só mudou de ideia por causa da música, voltou a compor só com os ouvidos sobre o piano e ouvindo o som vibrar no chão. Enquanto ele conduzia e tocava piano em silêncio a plateia como que em choque vibravam perplexos e emocionados.

\section{TRATAMENTO X FAMÍLIA}

A Academia Americana de Pediatria (2001) montou diversos quadros com diretrizes específicas quanto a forma e sequências de tratamentos da criança com DDA, bem como orientações a família e a escola com dicas de manejos com o intuito de ajudar 
a pessoa com DDA, possibilitando que todos aprendam em conjunto a lidar com os sintomas e as dificuldades acarretadas pelo transtorno nas interações e vivências, favorecendo através do trabalho e tratamentos amplos e diversificados, que todos saiam favorecidos no processo e com mais qualidade de vida e esperança de dias melhores em todos os espaços e ambientes ao longo de toda sua vida, orientações estas que perpassam desde orientação e conceitualizações sobre o que é o transtorno para que a família tenha domínio de conhecimento sobre toda a problemática pela qual seu filho passa, a terapias individuais e de grupo, tratamentos medicamentosos em casos que se fazem uso destes para ajudar a controlar as situações e dar mais qualidade de vida a pessoa com deficiente de atenção e hiperatividade e simultaneamente melhorando as interações entre a família e a criança ou adolescente que apresenta esse transtorno comportamental.. (DESIDÉRIO, 2007).

O medicamento mais usado é a Ritalina (metilfenidato) que pode causar dor de cabeça, mal-estar, náuseas, vômitos e tonturas, labilidade emocional, dor abdominal, comer compulsivamente e vorazmente ou ter redução e apetite, irritabilidade e alterações de sono conforme (TOPCZEWSKI, 2008).

Barkley (1998) acentua que não basta apenas medicar a criança, portanto a Ritalina não é resposta para todos os casos, sendo muito relativo a cada caso e circunstâncias. Parte do tratamento diz respeito a treinar os pais e professores com técnicas de manejo aliando os tratamentos, reforçando que não existe cura, mas um alivio dos sintomas e das comorbidades como depressão, baixa autoestima e baixo rendimento escolar.

Barkley como forma de orientar os pais relaciona por tópicos os pontos mais relevantes das estratégias necessárias a serem adotadas pelos pais nesse sentido com relação a falta de disciplina firme e táticas de controles ineficientes, onde os filhos se opõem e desobedecem e perturbam a paz. 
[...] Existem alguns princípios que os pais podem trabalhar com seus filhos para melhorar o comportamento deles, seus relacionamentos sociais e o ajuste geral em casa. Os pais devem: Barkley (2008, p. 207),

a) Compreender que, para poder controlar em casa o comportamento resultante do TDAH, é preciso ter um conhecimento correto do distúrbio e suas complicações,

b) Ser coerentes, previsíveis em suas ações e mostrar apoio às crianças em suas interações diárias, pois como foi dito, este não é apenas um problema que pode ser curado. O distúrbio afetará a criança durante toda sua vida.

c) Manter-se numa posição de intermediação entre a escola e outros grupos.

d) Dar instruções positivas.

e) Cuidar para que seus pedidos sejam feitos de maneira positiva ao invés de negativa.

f) Recompensar amplamente o comportamento adequado. Crianças com TDAH exigem respostas imediatas, frequentes, previsíveis coerentemente aplicadas ao seu comportamento.

g) Planejar adequadamente

h). Aprender a reagir aos limites de seu filho de maneira positiva e ativa. As regras devem ser claras e concisas. Atividades ou situações nas quais já ocorreram problemas, devem ser evitadas.

i). Punir adequadamente, porém compreendendo que a punição só trará uma modificação de comportamento para a criança com TDAH, se acompanhada de uma estratégia de controle. (BARKLEY, 2008, p. 207).

De acordo com Mattos (2001); Jones (2004) e Barkley (1998), os pais tem que ter autoridade e pulso firme, fazendo funcionar os combinados sem voltar atrás de suas palavras sob risco de perder autoridade e domínio das comportamentos com cada um cumprindo com sua parte dos acordos; também reforça a importância dos pais adquirirem conhecimentos e técnicas de manejos comportamentais para aprender a lidar com seus filhos com TDAH e para tal esquematizou o programa de aconselhamento ou treinamento de pais de crianças com TDAH, em dez sessões, divididas em duas horas distribuídos para cada pai individualmente, para a família ou grupos, com a ideia de que muitas dessas crianças possuem problemas 
comportamentais por falta de regras mais explicitas, sistemáticas e internalizadas com firmeza, e alerta para o risco de se aplicar regras demais as demais crianças, uma vez que tudo que é feito com demasia, a longo prazo principalmente na adolescência acaba por ser um motivo de rebeldia, muitos conflitos, problemas comportamentais e morais muito maiores, uma vez que muita regra e sem firmeza torna se algo flexível e aberto a rupturas e inversão de hábitos pelo bel prazer de testar e desafiar a autoridade mais imediata, nesse caso geralmente quem mais o enfrenta são os pais e mais tarde a escola e a sociedade, no que Rohde concorda quanto a busca de conhecimentos e o trabalho em parceria com a escola, visando além da inclusão e harmonia entre as partes, ter orientações quanto tratamentos terapêuticos, acompanhamentos e tratamento psiquiátrico para diminuir as angústias, ansiedades e possíveis depressões que são causas de muitos suicídios na adolescência.

O neurologista Doutor Abram Topczewski (1999) constata que a hiperatividade é familiar aos educadores, psicólogos e terapeutas e um grande dilema para muitas famílias, sendo que é se deve a um problema comportamental que dificulta as interações sociais em todos esses espaços, entretanto, no meio escolar devido as muitas exigências e cobranças acabam por complicar o problema todo em si, além de que a criança precisa de espaço para extravasar suas energias para aliviar seu stress e ajudar a lidar com sua agitação interna e motora e permanecendo restrito ao espaço de sala de aula e casa sem esse escape estratégico e oportuno finda-se que acumula energia e estimulo em excesso que prejudica-o em suas interações e vivencias, e muito mais quando sua condição não é aceita e tratada como tal por parte da escola e da família, o que com o tempo pode vir a irromper com crises de violência e criminalidade.

Rohde e Benzick (1999) trabalhando em parceria com os pais de crianças com TDAH, orientando-os a buscarem conhecimento em livros, vídeos e fitas, esquematizaram dez passos como orientação para os pais, sendo que primeiramente devem informar e dar um norte aos professores com relação ao que 
seu filho tem e oferecer apoio e suporte, compreensão e recursos, atuando de forma persistente, compromissada e tendo a humildade para reconhecer que precisa de ajuda para colaborar com a prática do programa, buscando melhor entender o que se passa com seu filho, emocional e psicologicamente, mental e fisicamente, para compreender do porquê de seu comportamento diferenciado das demais crianças.

Eis os dez passos do programa elaborados por Rohde e Benzick:

1 - O que é TDAH; 2-cabe aos pais conhecerem seus filhos e perceberem discernirem o que caracteriza a hiperatividade ou problemas na condução da educação destes; 3-dar instruções positivas com autoridade mas sem autoritarismos, gritos e aprendendo a ouvir e dialogar com seus filhos falas também pontuadas Freire 1983, bem como também justificar o porquê do não e do sim sem depreciá-los; 4-Recompensar (podendo se recorrer ao sistema de quadro de pontos, utilizando de reforço e de valorização e reconhecimento dos pontos positivos como talentos e habilidades de seus filho com TDAH.) desempenhos, tentativas, acertos e erros, como forma de motivar e trabalhar a autoestima, e respondendo sempre seus questionamentos para evitar crises de ansiedade;5- Escolher as batalhas ou trabalhar de forma firme, coesa, sem voltar atrás de palavras e promessas feitas, um sintoma de cada vez; 6 - Usar técnicas de "custo de resposta" -"custo de respostas", pois os castigos e punições não são uma medida adequada para justar condutas e comportamentos inadequados, há que se tomar cuidado e preferencialmente usar de técnica de pontos e de compensação e estímulos da autoestima e do desempenho, dedicação e esforço de seus filhos em obedecer, colaborar e mudar seus pontos fracos, jamais recorrer a punições e castigos para evitar futuras rebeldias e transtornos opositores entre outros possíveis fatores e comorbidades; 7 - Planejar adequadamente a rotina- cabe aos pais planejar e organizar esse ambiente familiar para facilitar as adequações e mudanças comportamentais e tudo mais que for preciso para o bem-estar de seu filho, cabe aos pais aprenderem a lidar de forma positiva e ativa para ajudar na auto estima de sua prole. 8 - Punir adequadamenteSe faz necessários que os pais se atentem e tomem cuidado com os castigos e 
punições os quais não são recomendáveis, com relação a comportamentos intencionais de enfrentamento e que coloquem em risco o filho com TDAH e outros, que sejam um caso de segurança e danos à saúde, devem ser chamados a responsabilidade e arcar com as consequências de seus atos de forma consciente e responsável; mas se o for impensada e impulsiva característica dos sintomas do TDAH, nesse caso se requer utilização de técnicas ou estratégias de controle, de correção do comportamento de forma positiva, firme e ativa; 9 - Construir ilhas de competência (ROHDE e BENZICK, 1999)

O autor acrescenta que, a criança não é o que o transtorno apresenta, ela é muito mais que isso, ela possui qualidades, habilidades, talentos, aptidões e é indispensável que se foque nesses aspectos e não do lado negativo de seus filhos, sempre motivando, incentivando, estimulando a aprimorando os pontos positivos, e ensinar a lidar com seus sintomas e características em casa e na escola para melhorar sua aprendizagem e desenvolvimento e as interações e sua autoestima para que venha a ter êxito e esperança de uma vida e futuro melhor, sendo necessário que os pais aprendam a respeitar, ouvir e procurar entender os comportamentos de seus filhos e diferenciar do transtorno daqueles intencionais.

As intervenções psicopedagógicas auxiliam também crianças com transtornos de comportamento e mais especificamente de aprendizagem, incluindo dislexia, discalculia. A função do psicopedagogo é dar o suporte de reforço nas disciplinas ou conteúdos em que a criança apresente uma grande dificuldade de aprendizagem, de forma lúdica, conforme Topczewski (1999), métodos didáticos alternativos para melhoria do comportamento e desenvolvimento pedagógico da criança hiperativa, tais quais:

Desenvolver atividades em pequenos grupos de forma inclusiva, com tarefas curtas e revezadas, motivar com sistema de recompensas ou elogios, fazer uso de recursos, técnicas e metodologias lúdicas, organização da rotina, chamar a responsabilidade quando fizer algo errado procurar se corrigir, trabalhar em equipe 
com todos envolvidos nas intervenções e tratamentos do mesmo; fazer explicações claras, objetivas e recapitulações a medida do necessário; se certificar que entenderam perguntando a eles; estimular dando responsabilidade como ajudante do dia do professor e coisas do tipo; estabelecer combinados lembrando-os sempre que necessário de forma tranquila; e manter os pais por perto orientando-os e encaminhando os a especialistas da área da saúde se for necessário.

Há as intervenções psicossociais dos psicólogos clínicos, e por fim as intervenções psicofarmacológicas administradas por psiquiatras e neurologistas especializados no sistema nervoso e sua função com relação ao comportamento dos seres humanos, sendo que o seu foco é a aprendizagem na sua área de atuação, se aproximando e buscando trabalhar em parceria com profissionais da Neuropsicopedagogia relacionando conceitos neurocientificos com embasamento da psicologia e da pedagogia. E relativamente a gravidade das comorbidades severas, se presentes ou não, há a fonoaudiologia no caso de déficit de atenção que apresentem problemas de linguagem ou comunicação. Sobre isso Rohde e Benczik (1999) falam da combinação das intervenções sequenciadamente, em primeiro lugar diz respeito a orientação familiar sobre o TDAH; tratamento psicoterápico da criança ou adolescente; reforços de conteúdos por parte dos psicopedagogos; administração de medicação; orientação da família com manejos e os professores com técnicas de manejo.

\section{ORIENTAÇÃO AOS PROFESSORES DO INDIVÍDUO COM DÉFICIT DE ATENÇÃO E HIPERATIVIDADE}

O que se constatou através desta pesquisa dos autores acima, foi que cerca de $98 \%$ dos professores não tem conhecimento de causa no que diz respeito ao $\mathrm{DAH}$, portanto, também em diferenciar o aluno hiperativo ou com déficit de atenção, de outros que apenas estão sem interesse em aulas desmotivantes e, portanto, somente desatento. 
Rohde e Benczik recomendam sugestões para o professor, que favorecerão principalmente o processo de aprendizagem da criança com TDAH, assim como sua inclusão social, a elevação de sua autoestima, redução de seu comportamento hiperativo e aumento de sua capacidade de atenção e concentração; realização de suas atividades de forma eficiente e com a colaboração entre ambas as partes durante todo o processo.

1) Sente com a criança ou adolescente a sós e pergunte como ele acha que aprende melhor. Frequentemente, terá sugestões valiosas.

2) Lance mãos de estratégias e recursos de ensino flexíveis até descobrir o estilo de aprendizado do aluno. Isso irá ajudá-lo a atingir um nível de desempenho escolar mais satisfatório

3) Encoraje uma estrutura para auto informação e monitoração. A cada semana, sente com a criança alguns minutos e dê-lhe um retorno sobre como ela está se saindo em sala de aula. Ouça a opinião dela sobre os progressos e dificuldades. É necessário que ela seja um agente ativo da aprendizagem.

4) Crie um caderno "casa-escola-casa". Isso é fundamental para melhorar a comunicação entre os pais e você.

5) Assinale e elogie os sucessos da criança tanto quanto forem possíveis. Ela já convive com tantos fracassos que precisa de toda estimulação positiva que puder obter.

6) Procure afixar as regras de funcionamento em sala de aula em lugar visível. As crianças sentem-se reasseguradas sabendo o que é esperado delas.

7) lembre-se as regras e instruções devem ser breves e claras. Use uma linguagem adequada para o nível de desenvolvimento da criança. Evite sentenças muito compridas.

8) Sempre que possível, transforme as tarefas em jogos. A motivação para a aprendizagem certamente aumentará.

9) Com um adolescente, estimule que ele tome nota dos pontos mais importantes do conteúdo e do que está pensando. Isso irá ajudá-lo a organizar-se melhor.

10) Escrever à mão é muito difícil para muitas destas crianças. Considere a possibilidade de usos de alternativas, como a digitação no computador.

RC: 60944

Disponível em: https://www.nucleodoconhecimento.com.br/educacao/professoresde-series 
11) Elimine ou reduza a frequência de testes cronometrados. Dificilmente, na vida real, a criança terá que tomar decisões tão rápidas. Estes testes apenas reforçam a impulsividade destes alunos.

12) Avalie mais pela qualidade e menos pela quantidade das tarefas executadas. O importante é que os conceitos estejam sendo aprendidos. (ROHDE e BENCZIK, 2010, p. 85, 86).

De acordo com Rohde e Benczik (2010) a criança que sofre com o TDAH tende a ter baixa autoestima, por isso torna-se muito importante os estímulos, elogios, reforços positivos para instigar e ajudar a acirrar os ânimos abatidos ante a tantas dificuldades e barreiras que a criança enfrenta diariamente por não conseguir dominar com êxito seus sintomas como um todo o que o atormenta por si só por não conseguir sobressair-se e atender as expectativas de seus familiares e por parte da escola e de todos a seu redor, que lhe enchem de cobranças e o estigmatizam por seus fracassos acadêmicos e sociais.

Rohde e Benczik (2010) aconselham o professor a sempre que possível planejar atividades lúdicas, em grupo ou duplas onde um se apoia no outro; além de estratégias com jogos, brincadeiras, intercalando as atividades que exigem mais atenção e concentração com outras mais lúdicas para não sobrecarregar a criança com tanta pressão e cobrança, dando tempo para respirar e facilitar o processo de voltar a se concentrar na atividade e paralelamente despertar o interesse e prazer pelas dinâmicas de sala de aula, tornando assim o dia a dia mais atrativo e prazeroso para todos os envolvidos no processo de ensinar e aprender.

Rhode et al. (2000) vem a contribuir com relação a importância das intervenções no âmbito da sala de aula, sob diversos aspectos, os quais são significativos para agregar no direcionamento do desempenho escolar, aconselhando-se a pensar numa sala de aula em que não tenha muitos alunos, tenha rotina para facilitar para favorecer a organização e equilíbrio emocional ao se saber o que esperar de cada sequência cotidiana; revezamento entre atividades que exijam maior atenção e outras mais lúdicas que envolvam movimentos; atividades não muito extensas e cansativas e bem explanadas do começo ao fim; um olhar e atenção mais atento e 
direcionado para a criança com TDAH inclusive colocando sua carteira na frente o mais próximo do professor para facilitar as mediações e intervenções necessárias quando este venha a se dispersar demais, afastando de estímulos excessivos como janelas, portas, decorações em demasia; recuperação paralela e reforço dos conteúdos trabalhados em sala para que seja garantido que ele consiga acompanhar todo o grupo e ter obter sucesso e êxito em seus estudos e vida acadêmica e se preciso for, caso demonstre dificuldades motoras se pensar em atividades que estimulem essas áreas em especifico de seu desenvolvimento necessárias durante o processo de ensino aprendizagem e ao longo de toda sua vida.

Rhode também defende a importância de trocas entre psiquiatras, psicólogos e professores com relação a orientação de manejo em sala de aula, da mesma forma o autor acredita no fator reforço como jogo de combinados, elogios ante seus progressos e habilidades na tentativa de conseguir que a criança se esforce para não falar o tempo todo atrapalhando o andamento da aula e procurando se controlar para permanecer sentado em sua carteira o maior tempo possível sem ficar circulando pela sala, pelas carteiras dos amigos e lixeiro, banheiro o tempo todo além de permitir que este quando muito agitado saia da sala para dar uma circulada e diminuir sua agitação e ansiedade sem prejuízo a sua aprendizagem até a criança aprender a se controlar melhor e diminuindo suas saídas. Fazendo suas lições por etapas com auxílio da professora para não acumular e não ficar muita coisa para fazer em casa, organizadas e divididas em pequenas partes de acordo com a capacidade dos alunos com TDAH, sempre as fazendo o melhor que puder no mesmo momento, conteúdos e conceitos desenvolvidos na sala de aula. Não soando como um castigo para as crianças e de devendo ser sucinto, objetivo, claro, conciso, bem explicado para que a criança consiga efetivar sua a tarefa sozinha tendo mediação dos pais somente a medida do necessário como um suporte para seu filho e forma de acompanhar o rendimento escolar destes. 
Outra estratégia eficiente para trazer a atenção da criança ou adolescente de volta ao que está se desenvolvendo no momento em sala de aula, é combinar um sinal ou chegar perto dela e falar num tom de voz diferente ou tocar levemente em sua carteira e assim por diante.

\section{MÉTODOS}

O presente estudo no primeiro momento, foi desenvolvido junto a professores de séries iniciais de $1^{\circ}$. ao $5^{\circ}$ ano da rede regular de ensino público da escola $\mathrm{X}$ do município de Araquari, Estado de SC, e da escola $X$ da rede estadual de ensino de Joinville, Estado de SC, para levantamento de dados sobre seus conhecimentos e experiência sobre transtorno de déficit de atenção e hiperatividadelimpulsividade; identificar como é o trabalho pedagógico e as maiores dificuldade do professor ao ensinar o aluno com TDAH, sendo, portanto alvo: a percepção do professor sobre o tema e sua práxis didática e pedagógica.

A direção da escola $X$ de Araquari foi procurada e recebeu a carta de apresentação e o termo de livre esclarecimento; frisou-se a importância da colaboração dos professores de séries iniciais ao responderem os questionários, sendo autorizada a falar com os professores pessoalmente. Dois deles responderam no momento, e os outros dois levaram para casa para responder "com calma" e entregar posteriormente.

$\mathrm{Na}$ escola $X$ de Joinville, foi realizado procedimento de apresentação semelhante e se deixou os questionários aos cuidados da auxiliar de direção, que os entregou aos professores.

Aplicou-se um questionário semiaberto, com questões referentes à formação dos professores; experiências na área com alunos com TDAH; questionando seus conhecimentos sobre o tema; sobre as dificuldades do professor em trabalhar em sala de aula de forma inclusiva contendo contemplando crianças com hiperatividade; como se sentiriam trabalhando com alunos com déficit de atenção $e$ 
hiperatividade/impulsividade; sobre a existência ou não de algum suporte didático, pedagógico e de especialistas no assunto e de acordo com seus pareceres, se a rede regular de ensino estaria preparada ou não para receber e trabalhar com essa parcela da sociedade, dando-se um tempo para responderem e após a devolutiva dos mesmos, se realizou a coleta de dados, seguida da análise de dados, o que de acordo com Bardin (1977); Berg (1998) e Bauer (2002).

A análise de conteúdo aplica-se a discursos e baseia-se na dedução ou inferências sistemáticas, de forma objetiva identificando algumas características da mensagem, por meio da construção de categorias, reunidas por temas de significação. (BERG, 1998; BAUER, 2002.)

Repetiu-se essa mesma pesquisa em março de 2020 visando efetivar uma atualização de dados, seguindo se todos os procedimentos para autorização dos mesmos na secretaria de Educação do Município de Araquari e na sequência em duas escolas sendo que em uma delas funciona simultaneamente turmas da rede estadual de ensino com outras turmas pertencentes a rede Municipal de ensino, somando-se portanto 3 escolas, e deu-se seguimentos aos procedimentos de coleta de dados e análise de forma crítica construtiva, através de um método analítico, investigativo, de forma objetiva e imparcial dos mais diversos conceitos, experiências e pensares, efetivando um comparativo entre os dois períodos.

\subsection{SUJEITOS DA PESQUISA}

Esta pesquisa deu-se em dois momentos e períodos distintos, 10 questionários respondidos no ano de 2014, sendo 5 deles numa Escola da Rede Estadual de Ensino do Município de Joinville e 5 outros respondidos por professores da Rede Municipal de Ensino do Município de Araquari. Em segundo momento em 2020, quando se aplicou 70 questionários em 2 Escolas da Rede Estadual de Ensino localizadas no Bairro Itinga, Município de Araquari, Estado de S.C. e 20 questionários aplicados numa Escola da Rede Municipal de Ensino também no Bairro Itinga, Munícipio de Araquari, S.C. De todos os profissionais abrangidos nessa pesquisa, no total 4 professores de cada Escola Estadual responderam os 
questionários totalizando 8 na rede estadual respondidos e 4 professores responderam da parte da Escola Municipal de Ensino, totalizando nas três escolas, 12 questionários.

\section{RESULTADOS E DISCUSSÃO DE 2014}

Formação - dos dez professores questionados:

04 - Curso superior que incluía capacitação sobre TDAH;

\section{Formação na graduação:}

08 - Oito são pedagogos;

01 - Professor de Educação Física; e

01 - Não respondeu esta questão.

\section{Nível de conhecimento sobre TDAH:}

P1 - "crianças hiperativas são crianças impacientes, agitadas e sem concentração";

P2 - "TDAH é um transtorno que impossibilita o educando no entendimento e assimilação";

P3 - "Hiperatividade é a dificuldade de concentração";

P4 - "A criança/pessoa com hiperatividade além de ser muito ativa ainda tem déficit de atenção";

P5 - "TDAH é um transtorno de 'base orgânica' associada a uma disfunção em áreas do córtex cerebral, conhecida como lobo pré-frontal. Sendo que quando seu funcionamento está comprometido, ocorrem dificuldades na concentração, memória, 
inquietude, impulsividade, desorganização, esquecimento e costumam ser agitados e possuem problemas para fazer as atividades até o final";

P6 - "Hiperatividade é um transtorno neurobiológico crônico, na grande maioria de ordem genética; o sétimo professor respondeu que as crianças hiperativas são muito ativas, que não param para aprender, precisam de 'limites' para realizar as atividades, mas são muito inteligentes, e que alguns são muito nervosos";

P8 - "A criança com TDAH, precisa de apoio de um segundo professor e para conseguir prestar atenção necessita de acompanhamento médico e medicamentoso";

P9 - "Um transtorno comportamental infantil mais frequentemente diagnosticado em meninos e que o transtorno pode ser herdado geneticamente, mas sua causa não é clara"; e

P10 - "Hiperatividade é dificuldade de concentração".

P7- Deixou a questão em branco

\section{Cursos de capacitação na área:}

02 - Tiveram capacitação na área de TDAH durante seus cursos de formação superior;

05 - Não possuem nenhum curso na área;

01 - Afirmou que "ainda não precisa de curso de capacitação na área".

Demais - questão ficou em branco/ não responderam

\section{Experiência anterior na área:}

02 - Já trabalham na área como segundos professores; 
08 - Nunca trabalharam com alunos com esse transtorno e uma das professoras disse que o filho "era" hiperativo, mas nunca atuou na área.

\section{Quanto como se sentem ou não preparado para trabalhar com alunos com} TDAH:

P1 - Se sente despreparado;

P2 - Se sente "bem, pois gosto do que faço";

P3 - "Se sente muito feliz quando os objetivos são alcançados";

P4 - "É difícil de aplicar as atividades";

P5 - Se referiu a dificuldade de estar passando o conteúdo sem o auxílio de um segundo professor;

P6 - "ainda precisa de curso de capacitação na área";

04 - Professores deixaram a questão em branco.

Como se sentiriam, ao trabalhar com crianças com TDAH:

P1 - Sentiria dificuldade quanto a aprendizagem destes;

P2 - Sentiria dificuldade quando o aluno não tomasse o medicamento;

P3 - Se sentiria afetado em relação ao comportamento, atenção e agressividade desses alunos;

P4 - Sua maior dificuldade é a falta de capacitação na área e o número elevado de alunos em sala;

P5 - Sua maior dificuldade seria a falta de laudo médico; 
P6 - Sua maior dificuldade é a falta de tempo para preparar o planejamento adaptado na escola, tendo que fazer em outros lugares.

Demais deixaram a questão em branco.

Quanto à rede de ensino estar preparada para receber e trabalhar com crianças com TDAH

03 professores responderam que sim;

03 afirmaram que não está;

02 não responderam;

01 cita a falta capacitação;

O $10^{\circ}$ que "depende da luta de outras pessoas competentes para dar o suporte. Se deixar as coisas acontecerem não se consegue auxílio nenhum".

Conforme a análise feita nos questionários com os dez professores, o resultado não condiz com prática de professores pesquisadores e aptos a atender às necessidades de seus alunos, independente de terem TDAH ou não. Os professores demonstraram desinteresse, desconhecimento, falta de experiência, escassez de suportes pedagógicos necessários a essa clientela, e falta de adequação da rede regular de ensino para atender de forma continuada e constante essa parcela da sociedade.

Quando não compreendido por pais e professores, seja por desconhecimento ou falta de habilidade em lidar com a criança hiperativa, a tendência é focar o olhar de forma crítica e negativa os problemas comportamentais, a agitação, os sintomas do TDAH, os quais prejudicam e muito na interação dessas pessoas com todos ao seu redor, causado pela ansiedade, impulsividade e dificuldade em manter o equilíbrio emocional, causando maiores prejuízos a si mesmos, à família e à escola. Quando o 
professor não está apto a promover a socialização deste aluno com o grande grupo ocorrem maiores dificuldades para estimular seu interesse no processo de aprendizagem; no entanto, o professor em posse de conhecimento sobre o transtorno pode reduzir sua impulsividade, aumentar sua capacidade de atenção e concentração nas atividades desenvolvidas em sala.

\subsection{ANÁLISE REALIZADA EM 2020}

\section{Formação: dos 12 professores questionados}

02 - Curso superior que incluía capacitação sobre TDAH;

10- Não tiveram capacitação na área

\section{Formação na graduação:}

01- Uma pedagoga e neuropsicopedagoga;

01- Pedagoga e com formação em Educação Especial

02- -Pedagogas com licenciaturas Plenas

01-Com formação em Artes Visuais

01 Formação em Letras atendendo turmas de $8^{\circ}$ do Ens. Fundamental e $1^{\circ}, 2^{\circ}$ e $3^{\circ}$ do Ensino Médio

01-Pós-graduada em geografia

01 - Pedagogo com formação em direito, logística, história e com pós-graduações

02- Não informaram a formação

01-Licenciatura em Matemática e especialista em Ensino 
01-Pós-graduada, mas não especificou a área de formação;

No total de 80 professores das três escolas 68 não responderam o questionário.

\section{Nível de conhecimento sobre TDAH:}

P1 - Um pouco (pesquisou em livros e artigos)

P2 - "dificuldade de aprendizagem"

P3 - "Doença crônica que inclui dificuldade de atenção, hiperatividade e impulsividade"

P4 - "conheço sobre suas características, as dificuldades que acarreta na aprendizagem, alguns métodos de avaliação e de intervenção"

\section{Nível de conhecimento sobre TDAH:}

P5- 'Diz "que é um transtorno do déficit de atenção com hiperatividade, caracterizado pela falta de atenção ]ao, por ser impulsivo e também por não parar quieto: "

P6- "O que eu sei é que a criança tanto com déficit de atenção quanto com hiperatividade tem dificuldade de concentração, e no caso de ser hiperativa, ela é inquieta, não consegue ficar muito tempo parada no lugar";

P7- Respondeu que é "transtorno de ansiedade";

P8- respondeu que sabe "'pouco" a respeito;

P9- "É um transtorno de hiperatividade e déficit de atenção; "

P10- "Humildemente busca por mais conhecimentos ao pedir " Gostaria de ter mais informações, sei o básico sobre o transtorno". 
P11 - cita que se trata de "Falta de concentração"

P12- Idem "Falta de concentração".

\section{Cursos de capacitação na área:}

01-“ Sim sou formada na Educação especial. Onde estudamos todas as deficiências, onde chamamos de deficiências múltiplas; "

01-Tem pós-graduação em psicopedagogia com ênfase na neurociência

10 - Não possuem nenhum curso na área;

\section{Experiência anterior na área:}

08- Sim já trabalharam anteriormente com crianças e ou adolescentes com déficit de atenção e hiperatividade; sendo que uma das professoras relata que "Sim. Pelo menos três anos de convivência com alunos com transtorno diagnosticado".

02-Não teve experiência anterior com alunos com déficit de atenção e hiperatividade;

01- Trabalha como segunda professora no $9^{\circ}$ ano, mas nunca teve experiência concreta com alunos com TDAH;

01-Um pouco, já trabalhei com crianças e adolescentes com déficit de atenção na rede municipal e estadual, quando tinham laudo por consequência tinham segunda professora para auxiliar em sala.

Se sentir ou não preparado para trabalhar com alunos com déficit de atenção e hiperatividade (TDAH):

P1 -“ Com poucos recursos, e pouco acompanhamento, mesmo com a Especialização (que foi uma procura individual), me sinto com muitas dúvidas"; 
P2 - "Me sinto normal, pois sou especialista nesta área, e não vejo problemas pois sou preparada para os desafios da escola regular, onde a inclusão se faz presente, como relatei, desde minha formação trabalho com esse público alvo e para mim não vejo dificuldade sem problemas";

P3 - "Péssimo, difícil trabalhar com o desconhecido";

P4 - Se sente "Incomodado e não preparado"

P5- Respondeu que não está preparada para trabalhar com TDAH;

P6- Fala que "Acredito que toda professora tem que estar preparada, desde que busquemos conhecimento sobre o caso; "

P7- diz que "Não trabalha com nenhuma criança ou adolescente com TDAH; "

P8- Relata que "Sinto muita dificuldade quando não tem professora para auxiliar, pois como são muitos alunos em sala, e dependendo da atividade proposta, os alunos com alguma deficiência sempre exigem maior atenção, além do tempo de aula que é curto para desenvolver a atividade.

Quanto ao se sentir preparada a mesma diz que "Um pouco sim, devido as experiências passadas e vividas em sala de aula com alunos com esses transtornos, mas sei que necessito de cursos e capacitação nessa área; "

\section{Se sentir ou não preparado para trabalhar com alunos com TDAH:}

P9- Relata que se sente "despreparada (auxílio com atividades, meios que possíveis) "Não" se sente preparada;

P 10- diz que se sente "muito perdida" e "Não" se sente preparada;

P11- diz que "Não!" 
P12- também diz "Não" se sentir preparada para trabalhar com crianças ou adolescentes com TDAH";

Com relação a haver ou não na escola em que atua, apoio didático/pedagógico que de suporte ao professor de crianças ou adolescentes com TDAH

01. "Faltam profissionais e materiais específicos para darem suporte no desenvolvimento de trabalhos com alunos hiperativos"

02. "Sim"

03. "Não estou a par"

04. "Sim";

05. Respondeu que "Não, assim como todas as escolas a inclusão é uma utopia, se o professor não se preparar por si, ele sofre o ano letivo";

06. Não respondeu essa questão;

07. Cita que o único suporte que há na escola ou na rede de ensino se restringe " somente ao material que o professor busca de forma individual";

08. "Não";

09. 01 Respondeu que "Temos Somente uma orientadora Pedagógica que auxilia os professores";

10. Cita que em todas as escolas as escolas "que trabalhei, nenhum apoio didático e pedagógico" que lhe de suporte e segurança.

11. Diz que sim

12. $\operatorname{Sim}$

RC: 60944

Disponível em: https://www.nucleodoconhecimento.com.br/educacao/professoresde-series 
No que diz respeito as maiores dificuldades e desafios de se trabalhar com crianças ou adolescentes com TDAH

P1- "A maior dificuldade é a irresponsabilidade dos pais, não fazem o tratamento adequado, contínuo com o seu filho, o qual se torna vítima da sociedade e da família; "

P2-respondeu que a maior dificuldade é a "falta de preparo"

P3- "Na dinâmica em sala, aprendizagem, principalmente em relação a leitura e escrita";

P4-Respondeu que a maior dificuldade dia respeito aos "Métodos e Estratégias"

No que diz respeito as maiores dificuldades e desafios de se trabalhar com crianças ou adolescentes com TDAH

P5- "não trabalho com alunos com TDAH; "

P6- "Acredito que seria um professor trabalhar sozinho em sala de aula sabendo que entre tantos alunos, tem um que precisa da sua atenção a mais que os outros alunos";

P7- "Falta de capacitação"

P8- "A quantidade numerosa de alunos em classe e o curto tempo de aula são fatores que dificultam uma maior atenção para com os alunos com tais transtornos, além do material didático e pedagógico que são escassos na escola; "

No que diz respeito as maiores dificuldades e desafios de se trabalhar com crianças ou adolescentes com TDAH

P9- "Nenhum apoio, Formação Continuada" 
P10-“Falta de Segundo Professor"

P11- "Falta de segundo Professor para auxiliar"

P12 -"A falta de paciência e conhecimento para lidar com eles"

Quanto à rede de ensino estar preparada para receber e trabalhar com crianças com TDAH

01- Professor responderam que não;

Respondeu que "Não, falta um trabalho mais intensificado de capacitação com os profissionais de educação; "

01. Respondeu que "Falta profissionais preparados, a inclusão não se resume só em matricular o aluno em turmas "normais";

02. Cita que "Acredito que o sistema da educação não está preparado e não quer assumir essa responsabilidade, a falta de respeito e interesse se torna visível. A lei é clara, mas os responsáveis não fazem a lei dar certo, pouco caso com nossos educandos diferente."

"Falta comprometimento dos nossos governos, prefeitos, diretores e diretores, orientadores, professores, supervisores, etc... A inclusão ainda está em constante transformação, e estamos aí lutando por direitos aos nossos diferentes";

Comenta que "Toda a rede pública ainda não, mas pela minha experiência como professora, em outras escolas, já existem escolas públicas bem preparadas para receber crianças inclusivas, com salas multifuncionais, materiais didáticos e 'pedagógicos, além de profissionais capacitados, porém isso não ocorre em todas as escolas públicas; " 
03. "Não. Os professores não estão preparados para atender crianças com essa condição por diversos motivos. Sempre busco saber das condições dos alunos que atendo, porém faço por minha conta.

04. Acredito que sim, que toda rede regular de ensino público tende a estar apto a trabalhar e promover a inclusão independente se o aluno tem ou não TDAH ou alguma outra deficiência, tem que trabalhar esse aluno junto com os demais promovendo sempre a inclusão entre os membros; "

05. Responde que "Sim".

06. "Não. Falta capacitação para os professores das disciplinas e poderia ter menos burocracia para contratação de professores pois o Estado não contrata mais se o aluno apresentar apenas o TDAH";

07. "Sim. Porém deverá haver segundo professor";

08. "Sim. Desde que haja segundo Professor";

09. "Não. Falta investimento do governo, preparação de profissionais para atuar com esses alunos, apoio dos responsáveis por essas crianças, agilidade e apoio das Unidades de Saúde".

Ter o DA faz que me sinta sempre castigado por coisas que estão fora de meu controle. Não quero me esquecer das coisas. Quisera atender a minha professora para aprender mais. Não gosto de envergonhar meus pais quando estamos com outras pessoas.

Eu gostaria de poder ir ao escritório de meu médico sem me desesperar por ter de esperar. Quero ser bom, comportar-me bem, tirar boas notas, ter mais amigos, não ser tão distraído. Quiser poder controlar a máquina que está dentro de mim, que faz com que me mova sem parar. Poder calar o que penso e não interromper e me meter em problemas. Quisera ser diferente, mas há algo dentro de mim que não me deixa. (BAUERMEISTER, p. 57 a 59)

O autor explica que crianças de 4 a 8 anos podem ser ensinadas com base em estímulos e respostas, fichas de compensações, orientando a evitar estímulos que a 
distraiam durante a realização as atividades e explicações da professora, arranjando-se estratégias para que evite de se levantar o tempo todo para conversar com os colegas, para ir até o lixeiro diversas vezes para apontar seus lápis, para buscar materiais emprestados com os colegas, em casa assistir televisão quando devia estar fazendo sua tarefa, jogando com os amigos e irmãos, atendendo telefone entre outros estímulos, se podendo fazer negociações após a conclusão das mesmas como forma de motivar, sejam com palavras de afirmações, carinho, algo que goste e anseie por fazer, e aos poucos essas crianças pequenas vão cristalizando esses hábitos a sua rotina conforme vão amadurecendo cognitivamente e ficando mais velhas. A forma acertada de se lidar com suas dificuldades inibitórias, aos poucos, dos 9 anos em diante as crianças tendem a começar a internalizar, as guias externas, as orientações de manejo dos pais, professores, psicólogos, neurologistas e psiquiatras, fonoaudiólogos e toda intervenção e recurso humano que venham a contribuir com uma melhora na sua qualidade de vida através de ajustes internos e externos dos sintomas originados do TDAH.

A memória de trabalho prejudicada pela falta de atenção e concentração deve melhorar, e consequentemente armazenagem dessas memórias de procedimentos conceituais e práticos que necessita no seu dia para desenvolver seus trabalhos cognitivamente e manualmente falando, da mesma forma vai aprimorando e desenvolvendo de acordo com a idade cronológica, mental e física as suas habilidades de linguagens internas, seus pensamentos e forma de se organizar e processar mentalmente tudo que lhe passa pela cabeça de forma ininterrupta, incessante e estressantemente emocional e cognitivamente e com o tempo fisicamente também quando chega a afetar a qualidade e quantidade de sono, durante os horários em que seu corpo grita por socorro, causando muito caos e desgaste, com o tempo tende a causar transtornos de ansiedade, muita angústia, depressão, transtornos alimentares para tentar compensar e controlar a ansiedade o que não foi ensinado em tempo hábil aos 4 a 5 anos em diante. 
Através dessa pesquisa atualizada no corrente mês do ano de 2020, constatou-se que as queixas dos professores no geral são constantemente sempre as mesmas, ou seja, os sintomas do TDAH como a dificuldade de atenção, concentração, de permanecer parado e sentado para ouvir, dificuldade de aprendizagem, ou seja as mesmas colocadas no ano de 2014 por outros professores, e no caso da dificuldade de aprendizagem possivelmente se deve à falta a dificuldade de atenção e conseguir manter a concentração devido a imaturidade de suas funções executivas localizadas no seu córtex pré frontal responsável pelo domínio inibitório de suas ações morais, éticas, posturais, comportamentais ou motoras, de atenção e concentração, sem os quais e sem uma aprendizagem e técnicas de manejos dessas dificuldades todo e qualquer ato de trabalho, memória de trabalho, internalização de conceitos teóricos e práticas e tudo mais torna-se inviável ou quase impossível, eis o porquê da dificuldade de aprendizagem e atrasos nos seus rendimentos escolares e sobe e desce de seus conceitos avaliativos e notas além de muitos motivos de reuniões, conversas e reclamações aos pais nas portas das salas ou reuniões de pais e mestres, conselhos de classes e tudo mais.

Pode - se concluir que estes últimos professores colaboradores se mostraram mais cientes da importância de se manterem capacitados para trabalhar com a inclusão, com ânsia por aprender mais, se capacitar não somente teoricamente como metodologicamente, munidos de técnica de manejo, recursos, suportes didáticos, pedagógicos e com recursos humanos especializados que fazem falta no dia a dia em sala de aula, com ajuda para fazer a diferença em sala de aula, trocas de experiência e vivências, saberes e informações que venham ao encontro de suas angústias e os auxilie em suas práxis junto a seus alunos os quais encontram- se desassistidos, deixando-se muito a desejar, principalmente por parte do governo anterior e do sistema de ensino em si. Ficando os alunos, a família e os professores a remar sozinhos, sendo que alguns deles inclusive desabafam que Ihes faltam a assistência e suporte de um segundo professor e de recursos específicos bem como orientações práticas e metodológicas conceituais e concretas. Queixam -se de falta de investimento em curso formativos, capacitações e profissionais capacitados e 
habilitados na área em questão, os quais enriqueceriam e poderiam contribuir e muito com nessa área agregando valores, práxis úteis e emergentes para suas bagagens, enquanto profissionais da educação e pilares da sociedade que são.

\section{CONSIDERAÇÕES FINAIS}

O transtorno de déficit de atenção e hiperatividade/impulsividade se divide em dois subtipos: hiperativos / impulsivos e desatentos, e ainda há os mistos; sendo este último o mais complexo de se manejar, pois além da dificuldade em controlar seus comportamentos, atitudes, impulsos, há a dificuldade de se concentrar em mais de uma coisa de cada vez, se dispersando fácil e rapidamente, o que impossibilita que internalize e memorize conceitos e falas de outros. No período das séries iniciais, o aluno está ainda a desenvolver seu caráter e personalidade, se o professor não tiver conhecimento sobre a existência do transtorno, seus sintomas, não conhecer seu aluno e o ambiente em que vive, haverá maior risco de comprometimento negativo da relação professor-aluno e desenvolvimento destes. Quando seus comportamentos, dificuldades de aprendizagem, de atenção e concentração, de interagir com as demais da turma, não são observadas nem identificadas pelo professor, podem ser mal interpretados e tratados indevidamente. Acredita-se ser o professor a fonte predominante para auxiliar no encaminhamento e orientação dos pais dessa criança a especialistas da área da saúde para verificar o que acontece, e a razão de seus sintomas, mas para tanto, precisa estar em constante aperfeiçoamento e busca de conhecimentos para melhor entender e trabalhar com seus alunos.

De acordo com Barkley (1998) e Rief (2001), se faz necessário que o professor reconheça, valorize e estimule as habilidades, talentos, aptidões e o real potencial do aluno com TDAH. O professor capacitado para trabalhar com pessoas com TDAH de forma equilibrada e criativa, tem a possibilidade de trabalhar segundo os interesse de seus alunos com projetos temáticos para aproveitar suas curiosidades e questionamentos de forma a ampliar seus interesses, aprendizagem e 
desenvolvimento de forma significativa, sempre dando voz e vez ao seus alunos, dando retornos ou feedbacks a seus posicionamentos e questionamentos, ampliando e construindo na coletividades saberes, conhecimentos, conceitos e hipóteses, preferencialmente com trabalhos em equipe, e como reforço tarefas de casa divididas em pequenas partes e que possam desenvolver em curto espaço de tempo enquanto ainda tem alguma habilidade de manter a concentração e interesse.

Conforme a análise feita nos questionários com os dez professores em 2014, o resultado não condiz com prática de professores pesquisadores aptos a atender às necessidades de seus alunos, independente de terem TDAH ou não. Os professores demonstraram desinteresse, desconhecimento, falta de experiência, escassez de suportes pedagógicos necessários e específicos a essa clientela e falta de adequação da rede regular de ensino para atender de forma continuada e constante essa parcela da sociedade, o que divergiu de forma bem contratada com a maioria dos últimos professores colaboradores.

Já nas pesquisas atualizadas realizadas no início do ano letivo em março de 2020, pode-se perceber que os professores colaboradores, se mostraram mais abertos e receptivos tanto a contribuir com a coleta de dados como na busca de maiores conhecimentos e capacitações na área da educação inclusiva, demonstraram interesse, expressaram se de forma crítica e construtiva, conscientes da necessidade de suas funções sociais na vida de sua clientela e sedentos por ajuda do sistema de ensino e das esferas governamentais no que tange a cursos de capacitações especificas, bem como em pensar, garantir , providenciar e manter um suporte de recursos de atendimentos especializados, recursos didáticos e apoio profissional pedagógico no dia a dia em sala de aula com segundos professores como ponte de ensino aprendizagem e orientadores e coordenadores que tenham domínio do assunto e boa vontade para socorrer nos momentos inusitados e imprevisíveis que venham a se apresentar uma vez que o ser humano é sempre uma caixinha de surpresa e toda ajuda sempre é bem vinda principalmente quando 
se diz respeito a inclusão escolar, tanto por parte dos pais como de toda comunidade escolar e rede de ensino.

\section{REFERÊNCIAS}

BARKLEY, Russel A. Transtorno de Déficit de Atenção/Hiperatividade. Porto Alegre: Artmed Editora, 2002.

BAUERMEISTER, José J. Hiperativo, Impulso, Distraído você me conhece?: guia para pais, professores e profissionais sobre déficit de atenção. São Paulo: Elevação, 2009.

BARKLEY, Russel A. (org.). Transtorno de déficit de atenção/hiperatividade: manual para diagnóstico e tratamento. 3aㅡ ed.- Porto Alegre: Artmed, 2008.

BENCZIK, Edyleine B. P.; ROHDE, Luis Augusto P. Transtorno de Déficit de Atenção/Hiperatividade: O que é? Como ajudar?. Porto Alegre: Artmed, 1999.

DESIDÉRIO, Rosimeire C. S.; MIYAZAKI, Maria Cristina de O. S.. Transtorno de Déficit de Atenção / Hiperatividade (TDAH): orientações para a família. Psicologia Escolar e Educacional, Campinas, v. 11, n. 1, p. 165-176, jan-jun. 2007. Semestral. Disponível em: https://www.scielo.br/scielo.php?script=sci_arttext\&pid=S1413$85572007000100018 \& \operatorname{lng}=e n \& n r m=i s o \& t$ Ing=pt. Acesso em: 27 ago. 2020.

DOMINGOS, N. A. M., e RISSO, K. R. O transtorno de déficit de atenção e a hiperatividade infantil. Em E. F. M. Silvares (Org.), Estudos de caso em psicologia clínica comportamental infantil. Campinas: Papirus.2000.

DSM IV: - Manual Estatístico Diagnóstico de Transtornos Mentais. Associação Americana de Psiquiatria, Editora Artes Médicas Sul, 4ª edição revisada. 1994.

DSM IV: - Manual Estatístico Diagnóstico de Transtornos Mentais. Associação Americana de Psiquiatria, Editora Artes Médicas Sul, 2002. 
DUPAUL, George J; GARY, Stoner, TDAH NAS ESCOLAS: estratégias de avaliação e Intervenção. São Paulo: M. Books, 2007.

FREIRE, P. Paulo Freire ao vivo. São Paulo: Loyola, 1983.

GOLDSTEIN, Sam, GOLDSTEIN, Michael. Hiperatividade: Como Desenvolver a Capacidade de Atenção da Criança. São Paulo: Papyrus, 1994.

GOLDSTEIN, Sam. Hiperatividade: Compreensão, Avaliação e Atuação: Uma Visão Geral sobre TDAH. Artigo: Publicação, novembro/2006.

GRILLO, Eugênio; SILVA, Ronaldo J. M. da. Manifestações precoces dos transtornos do comportamento na criança e no adolescente. J. Pediatr. (Rio J.), Porto Alegre, v. 80, n. 2, supl. p. 21-27, Apr. 2004 . Available from <http://www.scielo.br/scielo.php?script=sci_arttext\&pid=S0021 75572004000300004\&lng=en\&nrm=iso>. access on 29 Aug. 2020.

HALLOWELL, E.M.; RATEY, J.J.. Tendência à Distração: identificação e gerência do distúrbio do déficit de atenção (DDA) da infância à vida adulta. Rio de Janeiro: Rocco, 1999.

HARPIN, V. A.. The effect of $A D H D$ on the life of an individual, their family, and community from preschool to adult life. Archives Of Disease In Childhood. 90, (Suppl I), p. 2-7, 21 fev. 2005. Disponível em: https://www.ncbi.nlm.nih.gov/pmc/articles/PMC1765272/. Acesso em: 29 ago. 2020.

JONES, M. Hiperatividade: como ajudar seu filho. São Paulo: Plexus, 2004.

KAPLAN, H.I.; SADOCK, B.J.; GREBB, J.A.. Compêndio de Psiquiatria: Ciências do Comportamento e Psiquiatria Clínica.7 ed. Porto Alegre: Artmed, 1997.

MACHADO, Ligia de Fátima; CEZAR, Marisa Jesus. Transtorno de déficit de atenção e hiperatividade (tdah) em crianças: reflexões iniciais. Instituto 
Paranaense de Ensino, Maringá. 2007. Disponível em: http://www.educadores.diaadia.pr.gov.br/arquivos/File/2010/artigos_teses/Pedagogia /transtorno_de_deficit_de_atencao.pdf Acesso em: 04 nov. 2008.

MATTOS, P. No mundo da lua: Perguntas e respostas sobre transtorno do déficit de atenção com hiperatividade em crianças, adolescentes e adultos. São Paulo: Lemos, 2001.

MELLO, Flaviana Aparecida de; CARDOSO, Joseani Martins. Transtorno do Déficit de Atenção e Hiperatividade (tdah): Falta de Limites ou Hiperatividade Diagnosticada? Disponível em: https://www.portaleducacao.com.br/conteudo/artigos/informatica/transtorno-dodeficit-de-atencao-e-hiperatividade-tdah/67753\#> Acesso em: 29 ago. 2020.

PENNINGTON, B.F. Diagnóstico de distúrbios de aprendizagem: um referencial neuropsicológico. São Paulo: Pioneira, 1997.

RAPPLEY, M. D. Clinical practice. Attention deficit-hyperactivity disorder. New England Journal of Medicine. 352(2), 165-173. 2005. Disponível em: < https://www.nejm.org/doi/full/10.1056/NEJMcp032387\#article_citing_articles> Acesso em: 29 ago. 2020.

RIEF, S. Estratégias de intervenção na escola. Trabalho apresentado na II Conferência Internacional sobre o Transtorno de Déficit de Atenção/Hiperatividade. São Camilo: Centro de Convenções, 2001.

ROHDE, Luis A. e MATTOS, Paulo e cols. Princípios e práticas em transtorno de déficit de atenção/ hiperatividade/. Tdah. Porto Alegre: Artmed, 2008.

ROHDE, Luis Augusto; BARBOSA, Genário; TRAMONTINA, Silzá; POLANCZYK, Guilherme. Transtorno de déficit de atenção/hiperatividade. Revista Brasileira de Psiquiatria, São Paulo: v. 22, 2000. Disponível em: 
https://www.scielo.br/scielo.php?script=sci_arttext\&pid=\$1516-44462000000600003 Acesso em: 27 ago. 2020.

RUBINO, Rejane. Sobre o conceito de dislexia e seus efeitos no discurso social. Estilos clin., São Paulo , v. 13, n. 24, p. 84-97, jun. 2008 . Disponível em $<$ http://pepsic.bvsalud.org/scielo.php?script=sci_arttext\&pid=S1415$71282008000100007 \&$ Ing=pt\&nrm=iso>. Acesso em: 23 mar. 2020.

SANTA CATARINA. Governo do Estado. Secretaria de Estado da Educação. Política de Educação Especial do Estado de Santa Catarina. Fundação Catarinense de Educação Especial. Florianópolis, 2006

SENADO FEDERAL. Câmara dos Deputados. Projeto de Lei PL 7699/2006. Transformado na Lei Ordinária 13146/2015. Origem PLS 6/2003. Disponível em: $<$ https://www.camara.leg.br/proposicoesWeb/fichadetramitacao?idProposicao=33940 7> Acesso em: 29 ago. 2020..

SILVA, Ana Beatriz Barbosa. Mentes inquietas: TDAH: desatenção, hiperatividade e impulsividade. Rio de Janeiro: Objetiva, 2009.

TOPCZEWSKI, Abram. Hiperatividade: Como lidar? São Paulo: Casa do Psicólogo. 2008.

Enviado: Setembro, 2020.

Aprovado: Setembro, 2020. 